\title{
Photocatalysis of $\mathrm{WO}_{3}$ Nanoplates Synthesized by Conventional-Hydrothermal and Microwave-Hydrothermal Methods and of Commercial $\mathrm{WO}_{3}$ Nanorods
}

\author{
Jarupat Sungpanich, ${ }^{1}$ Titipun Thongtem, ${ }^{2,3}$ and Somchai Thongtem ${ }^{1,3}$ \\ ${ }^{1}$ Department of Physics and Materials Science, Faculty of Science, Chiang Mai University, Chiang Mai 50200, Thailand \\ ${ }^{2}$ Department of Chemistry, Faculty of Science, Chiang Mai University, Chiang Mai 50200, Thailand \\ ${ }^{3}$ Materials Science Research Center, Faculty of Science, Chiang Mai University, Chiang Mai 50200, Thailand \\ Correspondence should be addressed to Titipun Thongtem; ttpthongtem@yahoo.com \\ and Somchai Thongtem; schthongtem@yahoo.com
}

Received 6 May 2014; Accepted 5 July 2014; Published 7 August 2014

Academic Editor: Sheng-Rui Jian

Copyright (C) 2014 Jarupat Sungpanich et al. This is an open access article distributed under the Creative Commons Attribution License, which permits unrestricted use, distribution, and reproduction in any medium, provided the original work is properly cited.

\begin{abstract}
The degradation of methylene blue $(\mathrm{MB})$ dye by tungsten oxide $\left(\mathrm{WO}_{3}\right)$ photocatalyst synthesized by the $200^{\circ} \mathrm{C}$ conventionalhydrothermal $(\mathrm{C}-\mathrm{H})$ and $270 \mathrm{~W}$ microwave-hydrothermal $(\mathrm{M}-\mathrm{H})$ methods and commercial $\mathrm{WO}_{3}$ was studied under UV light irradiation for $360 \mathrm{~min}$. The photocatalysts were characterized by X-ray diffraction (XRD), scanning electron microscopy (SEM), transmission electron microscopy (TEM), Fourier transform infrared (FTIR) spectroscopy, Raman spectrophotometry, and UV visible spectroscopy to determine phase, morphology, vibration mode, and optical property. The BET analysis revealed the specific surface area of $29.74,37.25$, and $33.56 \mathrm{~m}^{2} / \mathrm{g}$ for the $\mathrm{C}-\mathrm{H} \mathrm{WO}_{3}$ nanoplates, $\mathrm{M}-\mathrm{H} \mathrm{WO}_{3}$ nanoplates, and commercial $\mathrm{WO}_{3}$ nanorods, respectively. In this research, the $\mathrm{M}-\mathrm{H} \mathrm{WO}$ nanoplates have the highest photocatalytic efficiency of $90.07 \%$ within 360 min, comparing to the $\mathrm{C}-\mathrm{H} \mathrm{WO}$ nanoplates and even commercial $\mathrm{WO}_{3}$ nanorods.
\end{abstract}

\section{Introduction}

In the past decade, nanostructured materials with zerodimensional quantum dots, one-dimensional nanofibers, nanotubes, and nanorods, and two-dimensional nanoplates and nanodisks have been widely synthesized and studied of their novel properties which are different from their counterparts [1]. Particularly, transition metal oxide based nanostructured semiconductors have become a rapid expansion in modern materials science, physics, and chemistry $[2,3]$. Tungsten oxide is an $n$-type semiconductor having attractive properties, especially as photochromic and electrochromic materials, and novel potential applications for using as gas sensors [3-5], humidity sensors [6], electrochromic devices [7], and photocatalysts $[1,5,8,9]$. During the last several decades, nanostructured $\mathrm{WO}_{3}$ has been synthesized by different processes: hydrothermal method $[5,9,10]$, microwave radiation [11], microwave plasma [12], microwave-assisted hydrothermal synthesis $[8,13]$, and sol-gel $[6,7]$. Most previous approaches to the synthesis of $\mathrm{WO}_{3}$ nanomaterials such as conventional-hydrothermal and microwave-hydrothermal methods have several advantages. Komarneni [14] reported that these methods consumed less energy and were costeffective and environmental friendly, and that the products are high purified single crystal. Although the hydrothermal process is slow kinetics at any given temperature, a combination of microwave and hydrothermal systems has been used to increase the kinetics of crystallization [14]. Due to the environmental remedy and energy-saving, photocatalytic semiconductors have been carried out. Sun et al. [15] described two main limitations for the wide use of the semiconductors: the low solar energy conversion efficiency due to their wide band gap and the high recombination rate of photo-induced electron-hole pairs. $\mathrm{WO}_{3}$ as one of the photocatalytic materials has been extensively investigated, mainly due to its high activities for hydrogen evolution from water and degradation 
of pollutants for water treatment $[9,16,17]$. The physical and chemical properties of the solid semiconductor surfaces are controlled by the synthesis method [18]. In the previous research [13], $\mathrm{WO}_{3}$ nanoplates were successfully synthesized by a $270 \mathrm{~W}$ microwave-hydrothermal reaction for $180 \mathrm{~min}$ and the formation mechanism was also proposed according to the experimental results. At present, photocatalysis of $\mathrm{WO}_{3}$ nanoplates synthesized by the conventional-hydrothermal $(\mathrm{C}-\mathrm{H})$ method at $200^{\circ} \mathrm{C}$ for $12 \mathrm{~h}, \mathrm{WO}_{3}$ nanoplates synthesized by the $270 \mathrm{~W}$ microwave-hydrothermal $(\mathrm{M}-\mathrm{H})$ method for 180 min [13], and commercial (com) $\mathrm{WO}_{3}$ nanorods was investigated by determining the photodegradation of methylene blue $(\mathrm{MB})$ dye under UV light irradiation.

\section{Experimental Procedure}

2.1. Synthesis. To synthesize $\mathrm{WO}_{3}$ nanoplates, $1 \mathrm{mmol}$ sodium tungstate $\left(\mathrm{Na}_{2} \mathrm{WO}_{4} \cdot 2 \mathrm{H}_{2} \mathrm{O}, 99.0 \%\right)$ and $0.2 \mathrm{~g}$ citric acid $\left(\mathrm{C}_{6} \mathrm{H}_{8} \mathrm{O}_{7} \cdot \mathrm{H}_{2} \mathrm{O}\right)$ were dissolved in $40 \mathrm{~mL}$ deionized water with $10 \mathrm{~min}$ vigorous magnetic stirring till complete dissolution. Subsequently, $37 \% \mathrm{HCl}$ was dropped to the solution until $\mathrm{pH}$ reaching 1 . Then the solution was vigorously stirred by a magnetic stirrer for $30 \mathrm{~min}$ until the turbid yellow solution was obtained. Each of the turbid yellow solutions was transferred into Teflon lined stainless steel autoclaves, which were heated at 120,160 , and $200^{\circ} \mathrm{C}$ for $12 \mathrm{~h}$. In the end, the autoclaves were naturally cooled to room temperature. The as-synthesized yellow precipitates were washed with ethanol and distilled water three times and dried at $80^{\circ} \mathrm{C}$ for $24 \mathrm{~h}$ for further studies. The system was also processed by the $270 \mathrm{~W}$ microwave-hydrothermal reaction for $180 \mathrm{~min}$.

2.2. Characterization. The final products were characterized by Rigaku MiniFlex X-ray diffractometer with $\mathrm{Cu}-\mathrm{K}_{\alpha}$ radiation $(\lambda=1.54178 \AA)$ ranging from $10^{\circ}$ to $80^{\circ}$, in combination with database of the Joint Committee on Powder Diffraction Standards (JCPDS) [19]. The scanning electron microscopic (SEM) images were carried out by field emission scanning electron microscopy (JEOL JSM-6335F). Transmission electron microscopic (TEM) and high-resolution transmission electron microscopic (HRTEM) images and selected area electron diffraction (SAED) pattern were taken on a transmission electron microscope (JEOL JEM-2010) accelerating at a voltage of $200 \mathrm{kV}$. Fourier transform infrared (FTIR) spectra were recorded on a Bruker Tensor 27 spectrometer with $\mathrm{KBr}$ as a diluting agent and operated in the range of $400-4000 \mathrm{~cm}^{-1}$. Raman spectra were recorded on a T64000 HORIBA Jobin Yvon spectrometer using a $50 \mathrm{~mW}$ and $514.5 \mathrm{~nm}$ wavelength Ar green laser. UV-visible absorption spectra were recorded on a Lambda 25 Perkin Elmer spectrometer using a UV lamp with $1 \mathrm{~nm}$ resolution ranging from 300 to $1000 \mathrm{~nm}$. The Brunauer-Emmett-Teller (BET) surface area was determined by a Quantachrome Autosorb 1-MP.

2.3. Photocatalysis. Photocatalytic activities of the $\mathrm{WO}_{3}$ nanoplates synthesized by the $\mathrm{M}-\mathrm{H}$ and $\mathrm{C}-\mathrm{H}$ methods and the commercial $\mathrm{WO}_{3}$ (Merck) nanorods were tested in

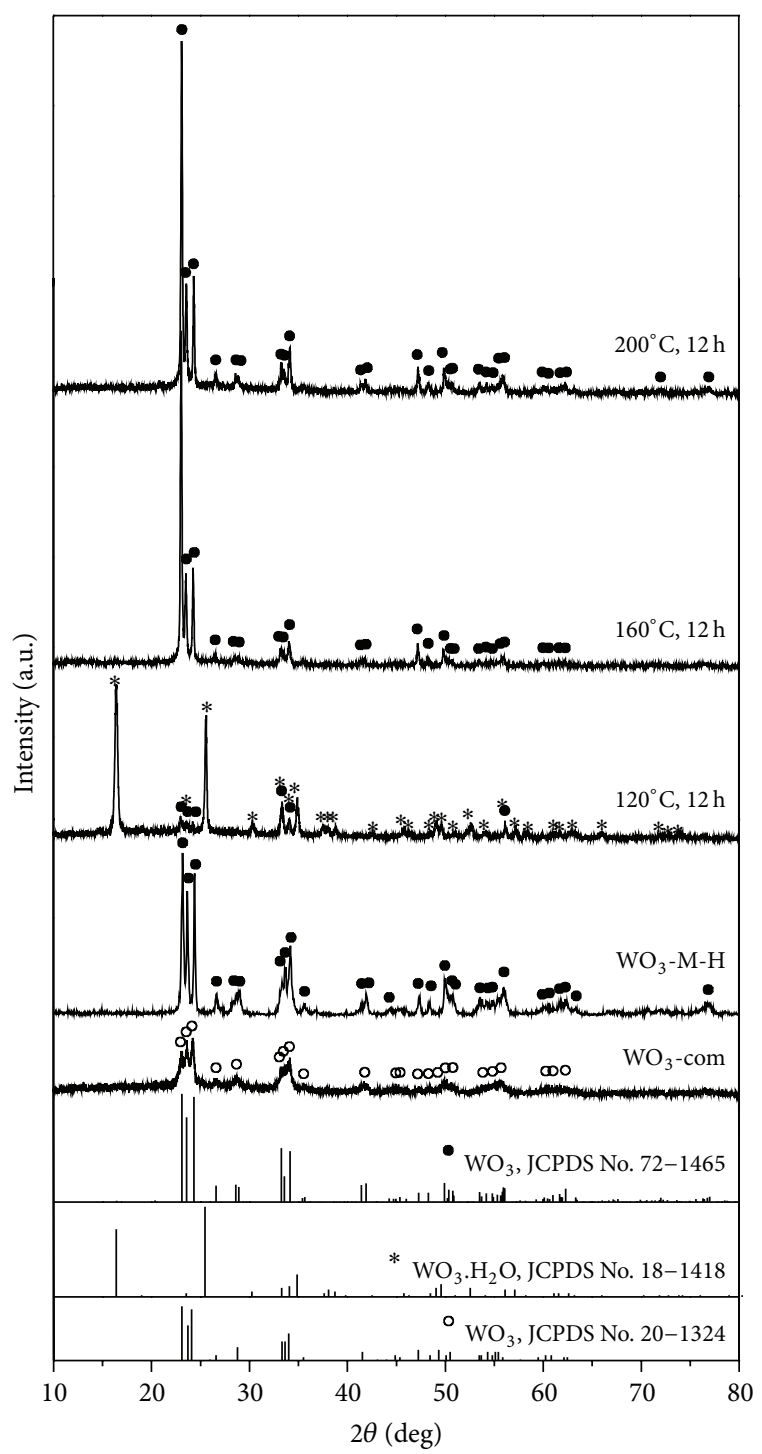

FIGURE 1: XRD patterns of the products synthesized by the C-H at 120,160 , and $200^{\circ} \mathrm{C}$ for $12 \mathrm{~h}$ and $\mathrm{M}-\mathrm{H}$ at $270 \mathrm{~W}$ for $180 \mathrm{~min}$ and commercial (com) $\mathrm{WO}_{3}$.

a methylene blue $\left(\mathrm{C}_{16} \mathrm{H}_{18} \mathrm{~N}_{3} \mathrm{SCI}, \mathrm{MB}\right)$ aqueous media under UV radiation. The initial concentration of $100 \mathrm{~mL}$ aqueous $\mathrm{MB}$ solution was set as $1 \times 10^{-5} \mathrm{~mol} / \mathrm{L}$ and loaded with $0.1 \mathrm{gWO}_{3}$. The suspension was irradiated by a $18 \mathrm{~W} \mathrm{UV}$ lamp with the average light intensity of $50.7 \mathrm{~W} / \mathrm{m}^{2}$. The concentration of $\mathrm{MB}$ was traced by UV-visible spectroscopy (Lambda 25 Perkin Elmer) in the range of 450-900 nm and the absorbance at the characteristic band of $664 \mathrm{~nm}$ was used to determine $\mathrm{MB}$ concentration.

\section{Results and Discussion}

3.1. XRD. Comparing XRD spectra (Figure 1 ) of the products synthesized by the C-H method at 120,160 , and $200^{\circ} \mathrm{C}$ for $12 \mathrm{~h}$ with the JCPDS database $\left(\mathrm{WO}_{3}\right.$, No. 72-1465) [19], they corresponded with pure monoclinic crystal system and P21/n 


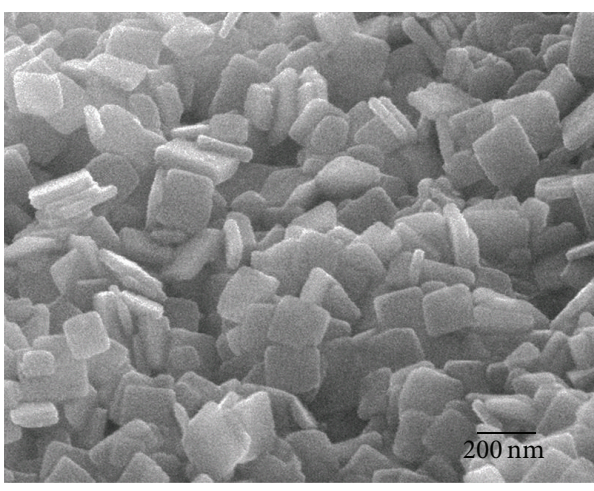

(a)

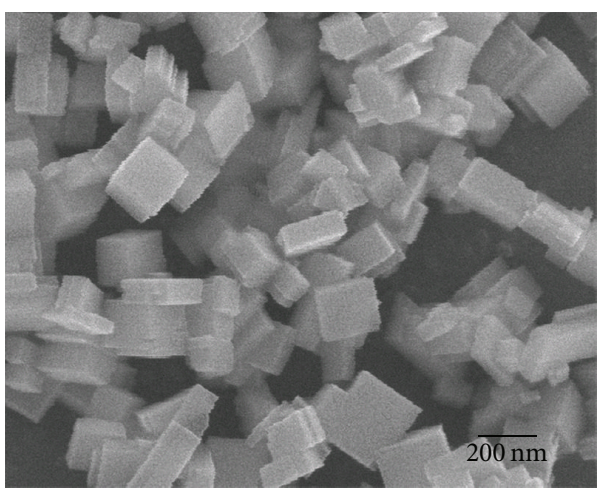

(c)

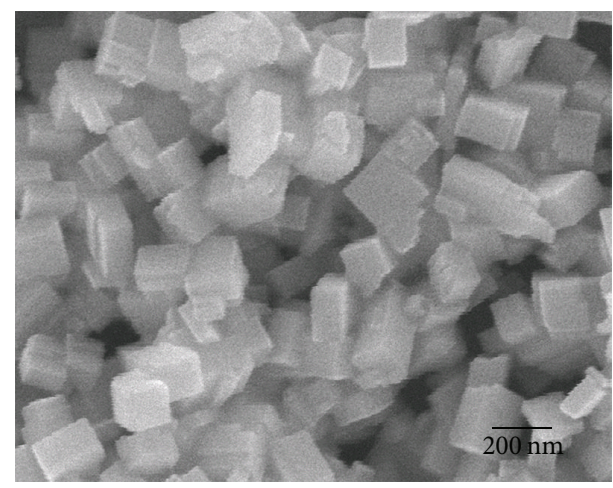

(b)

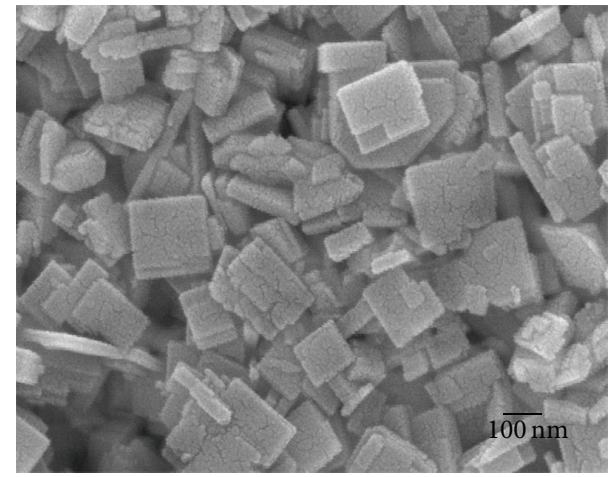

(d)

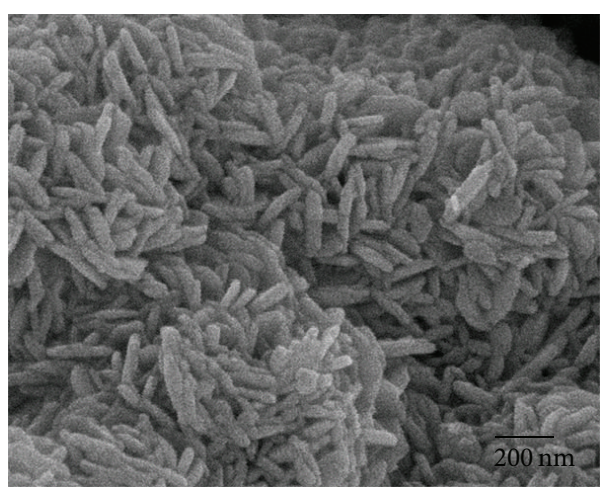

(e)

Figure 2: SEM images of the products, respectively, synthesized by the (a)-(c) C-H at 120,160 , and $200^{\circ} \mathrm{C}$ for $12 \mathrm{~h}$ and (d) $\mathrm{M}-\mathrm{H}$ at $270 \mathrm{~W}$ for 180 min and (e) commercial $\mathrm{WO}_{3}$.

space group at the synthesis temperatures of 160 and $200^{\circ} \mathrm{C}$ for $12 \mathrm{~h}$. At $120^{\circ} \mathrm{C}$, the product was composed of mixed phases of monoclinic $\mathrm{WO}_{3}$ and orthorhombic $\mathrm{WO}_{3} \cdot \mathrm{H}_{2} \mathrm{O}$ (JCPDS No. 18-1418) [19]. Upon increasing the operation temperature to 160 and $200^{\circ} \mathrm{C}$, pure monoclinic phase of $\mathrm{WO}_{3}$ was detected. Their XRD intensity peaks were strengthened in sequence with the increase in the test temperature from $160^{\circ} \mathrm{C}$ to $200^{\circ} \mathrm{C}$. In addition, the diffraction peaks of $\mathrm{WO}_{3}$ synthesized by $270 \mathrm{~W}$ microwave-hydrothermal processed for $180 \mathrm{~min}$ [13] are also identical to the monoclinic phase of the JCPDS No. 72-1465 [19]. For commercial $\mathrm{WO}_{3}$, the XRD pattern confirmed that the powder was composed of orthorhombic phase of $\mathrm{WO}_{3}$ (JCPDS No. 20-1324) [19].
3.2. SEM. Morphologies of the products synthesized at 120 , 160 , and $200^{\circ} \mathrm{C}$ for $12 \mathrm{~h}$ were characterized by SEM as shown in Figures 2(a)-2(c). It can be clearly seen that irregular nanoplates of the products gradually transformed into completely rectangular shape by increasing the synthesis temperature. The particles were randomly oriented in different directions as those of the previous report [13]. The C$\mathrm{H}$ synthesis surface of $\mathrm{WO}_{3}$ was smoother than the $\mathrm{M}-\mathrm{H}$ synthesis one (Figure 2(d)). Some traces of cracks were also detected on the $\mathrm{M}-\mathrm{H}$ rectangular nanoplates. These cracks can play the role in promoting the product porosity. In this research, the $\mathrm{C}-\mathrm{H}$ nanoplates are $50-100 \mathrm{~nm}$ thick, thicker than $\mathrm{WO}_{3}$ nanoplates of the $\mathrm{M}-\mathrm{H}$. These imply that stability 


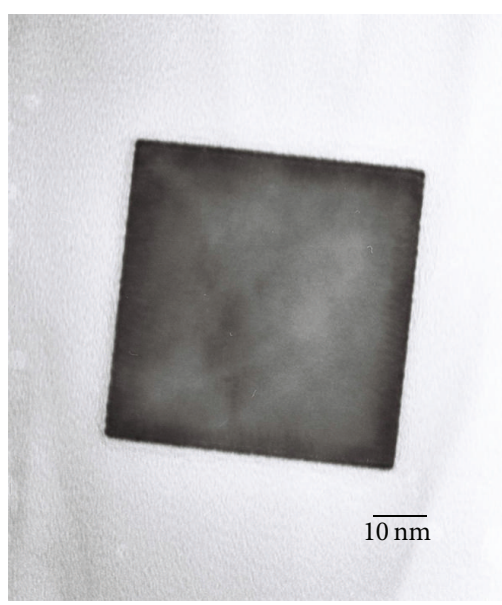

(a)

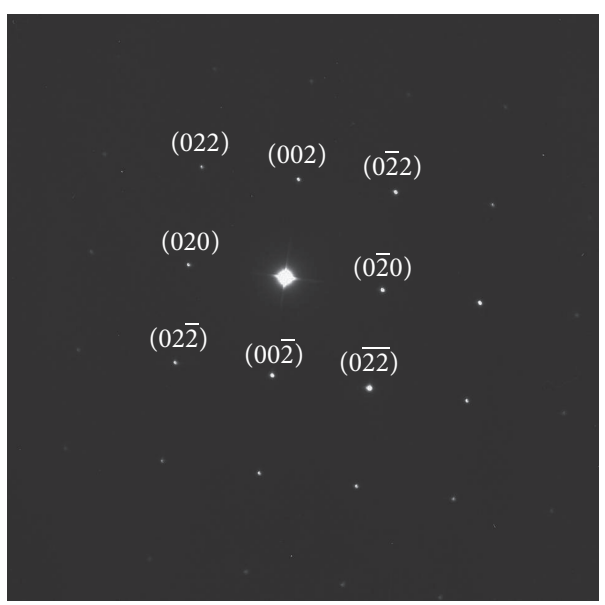

(b)

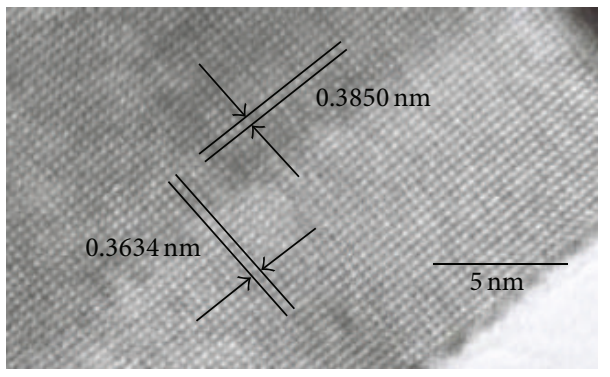

(c)

Figure 3: (a) TEM image, (b) SAED pattern, and (c) HRTEM image of $\mathrm{WO}_{3}$ synthesized by the C-H at $200^{\circ} \mathrm{C}$ for $12 \mathrm{~h}$.

of the pressure, temperature, and prolonged time can play a role in the crystal growth. The growth mechanism can be explained as follows: tiny nuclei formed by the reaction of $\mathrm{Na}_{2} \mathrm{WO}_{4} \cdot 2 \mathrm{H}_{2} \mathrm{O}$ and $\mathrm{C}_{6} \mathrm{H}_{8} \mathrm{O}_{7} \cdot \mathrm{H}_{2} \mathrm{O}$ in the solution with the $\mathrm{pH}$ of 1 and grew as orthorhombic $\mathrm{WO}_{3} \cdot \mathrm{H}_{2} \mathrm{O}$ irregular nanoplates at $120^{\circ} \mathrm{C}$. By increasing the temperature to 160 and $200^{\circ} \mathrm{C}$, monoclinic $\mathrm{WO}_{3}$ rectangular nanoplates with anisotropic growth rate were detected, especially, at $200^{\circ} \mathrm{C}$. It should be noted that the growth of $\mathrm{WO}_{3}$ nanoparticles could be changed during phase transformation and was controlled by citric acid [13]. The SEM image of commercial $\mathrm{WO}_{3}$ was also shown in Figure 2(e). It was composed of nanoparticles clustered together in the shape of nanorods with $<100 \mathrm{~nm}$ diameter and $200 \mathrm{~nm}$ length.

3.3. TEM. The morphology and phase of the product synthesized by the $\mathrm{C}-\mathrm{H}$ at $200^{\circ} \mathrm{C}$ for $12 \mathrm{~h}$ were characterized by TEM, HRTEM, and SAED and are shown in Figure 3. In this research, the $\mathrm{WO}_{3}$ product was shaped like rectangular nanoplates with the width and length of several $10 \mathrm{~nm}$. SAED pattern of the product was indexed [19] to correspond with the $\left(\begin{array}{lll}0 & 2 & 2\end{array}\right),\left(\begin{array}{lll}0 & 0 & 2\end{array}\right),\left(\begin{array}{lll}0 & -2 & 2\end{array}\right),\left(\begin{array}{lll}0 & -2 & 0\end{array}\right),\left(\begin{array}{lll}0 & -2 & -2\end{array}\right),\left(\begin{array}{lll}0 & 0 & -2\end{array}\right)$, $\left(\begin{array}{lll}0 & 2 & -2\end{array}\right)$, and $\left(\begin{array}{lll}0 & 2 & 0\end{array}\right)$ planes, specified as single crystalline $\mathrm{WO}_{3}$ [19]. The electron beam was in the $\left[\begin{array}{lll}1 & 0 & 0\end{array}\right]$ direction. The HRTEM image of the product revealed the presence of lattice plane separation of $0.3850 \mathrm{~nm}$ and $0.3634 \mathrm{~nm}$ corresponding to the interlayer stacking of the $\left(\begin{array}{lll}0 & 0 & 2\end{array}\right)$ and
(2 00 0) crystallographic planes of $\mathrm{WO}_{3}$ (JCPDS No. 72-1465) [19], respectively.

3.4. FTIR. The FTIR spectra (Figure 4(a)) provided further insight into the structure of the products synthesized by the $\mathrm{C}-\mathrm{H}$ at different temperatures for $12 \mathrm{~h}$ and commercial $\mathrm{WO}_{3}$. At $120^{\circ} \mathrm{C}$ synthesis, the major vibration modes associated with $\mathrm{O}-\mathrm{H}$ stretching of residual water was detected at $3655-3122 \mathrm{~cm}^{-1}, \mathrm{C}=\mathrm{O}$ stretching modes at $1626 \mathrm{~cm}^{-1}, \mathrm{C}-\mathrm{O}$ stretching modes of carboxyl at $948 \mathrm{~cm}^{-1}, \mathrm{O}-\mathrm{W}-\mathrm{O}$ stretching modes at 814 and $746 \mathrm{~cm}^{-1}$, and $\mathrm{W}-\mathrm{O}-\mathrm{W}$ stretching modes at $669 \mathrm{~cm}^{-1}$ [20-23]. Upon increasing the temperature from $120^{\circ} \mathrm{C}$ to $160^{\circ} \mathrm{C}$ and $200^{\circ} \mathrm{C}$, the $\mathrm{O}-\mathrm{H}$ and $\mathrm{C}=\mathrm{O}$ stretching modes were no longer detected. For commercial $\mathrm{WO}_{3}$, the observed peak was assigned to $\mathrm{W}-\mathrm{O}$ bonding.

3.5. Raman Analysis. A definite existence of the products synthesized by the $\mathrm{C}-\mathrm{H}$ at different temperatures for $12 \mathrm{~h}$ and commercial $\mathrm{WO}_{3}$ was revealed by Raman analysis (Figure 4(b)). For $\mathrm{WO}_{3}$ synthesized at 160 and $200^{\circ} \mathrm{C}$ and commercial $\mathrm{WO}_{3}$, two main peaks are typical O-W-O stretching modes of crystalline $\mathrm{WO}_{3}$ at $802 \mathrm{~cm}^{-1}$ (symmetric) for the shorter bonds, and $712 \mathrm{~cm}^{-1}$ (asymmetric) for the longer ones. Weak peaks at $610 \mathrm{~cm}^{-1}$ are assigned as the $\mathrm{O}-\mathrm{W}-\mathrm{O}$ stretching modes of $\mathrm{WO}_{3}$. Those at 325, 273, and $241 \mathrm{~cm}^{-1}$ are specified as $\mathrm{W}-\mathrm{O}-\mathrm{W}$ bending modes of the 


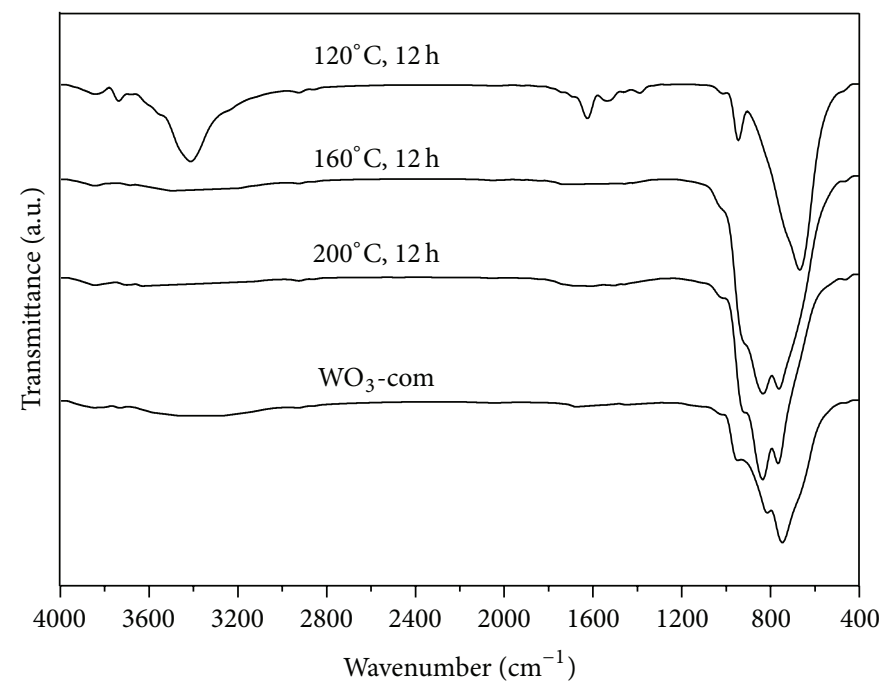

(a)

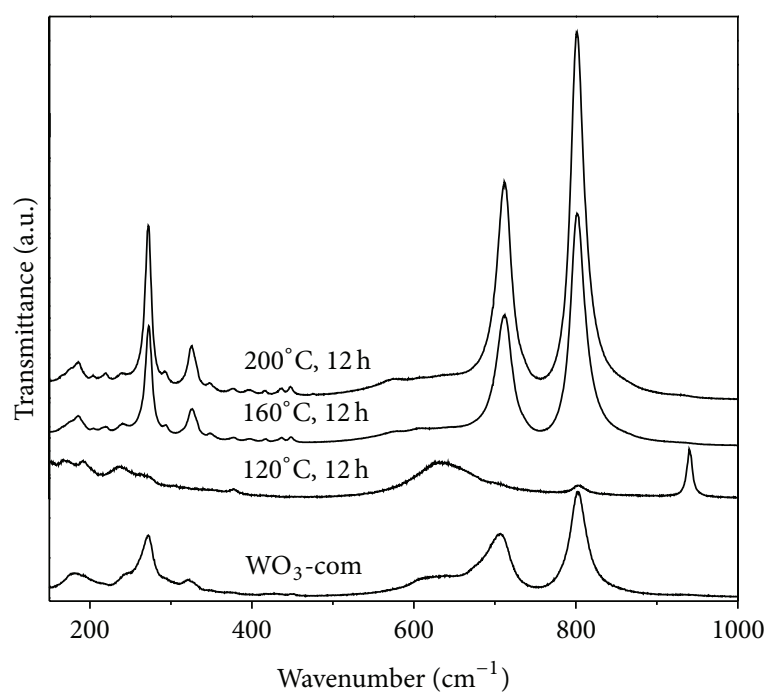

(b)

FIgURE 4: (a) FTIR and (b) Raman spectra of the products synthesized by the $\mathrm{C}-\mathrm{H}$ at 120,160 , and $200^{\circ} \mathrm{C}$ for $12 \mathrm{~h}$ and commercial WO .

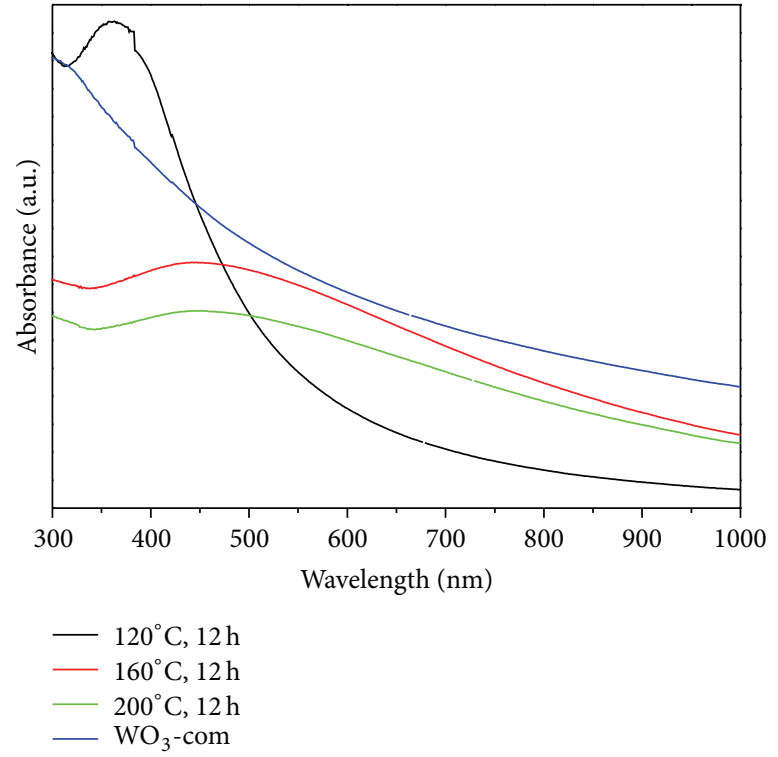

(a)

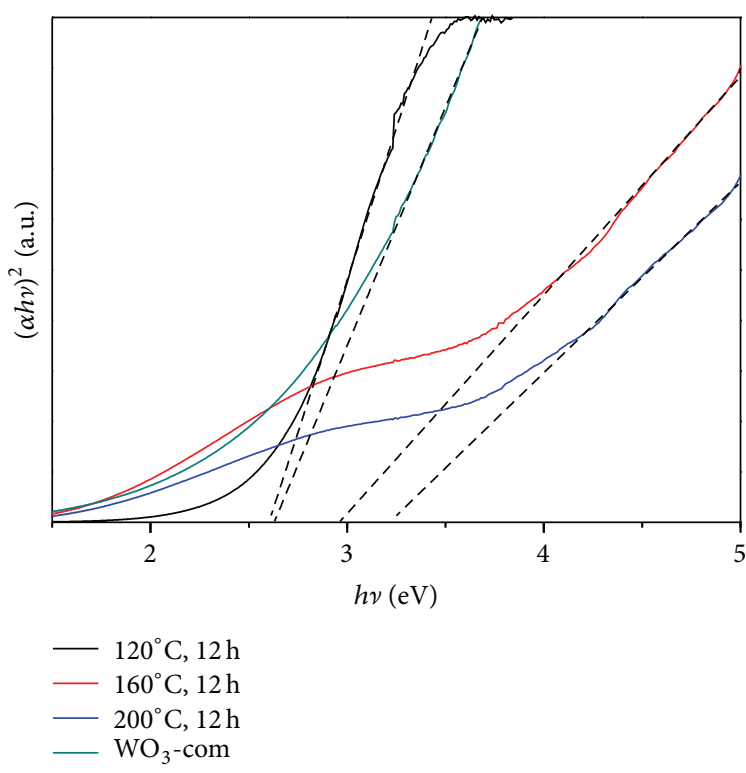

(b)

FIGURE 5: (a) UV-visible absorption and (b) the plot of $(\alpha h \nu)^{2}$ versus $h \nu$ of the products synthesized by the $\mathrm{C}-\mathrm{H}$ at 120,160 , and $200^{\circ} \mathrm{C}$ for $12 \mathrm{~h}$ and commercial $\mathrm{WO}_{3}$.

bridging oxygen. The peaks at $186 \mathrm{~cm}^{-1}$ are attributed to the lattice vibration. Additional mode belonging to $\mathrm{W}=\mathrm{O}$ stretching of the product processed at $120^{\circ} \mathrm{C}$ for $12 \mathrm{~h}$ was also detected at $940 \mathrm{~cm}^{-1}[20,23-27]$.

3.6. UV-Visible Absorption. UV-visible absorption of the products synthesized by the $\mathrm{C}-\mathrm{H}$ at different temperatures for $12 \mathrm{~h}$ and commercial $\mathrm{WO}_{3}$ is shown in Figure 5. For crystalline semiconductors, the UV absorption near band edge follows the following Wood and Tauc equation [28]:

$$
\alpha h v=\left(h v-E_{g}\right)^{n}
$$

where $\alpha$ is the absorbance, $h$ is the Planck constant, $v$ is the photon frequency, $E_{g}$ is the energy gap, and $n$ is a pure number associated with the different types of charged 


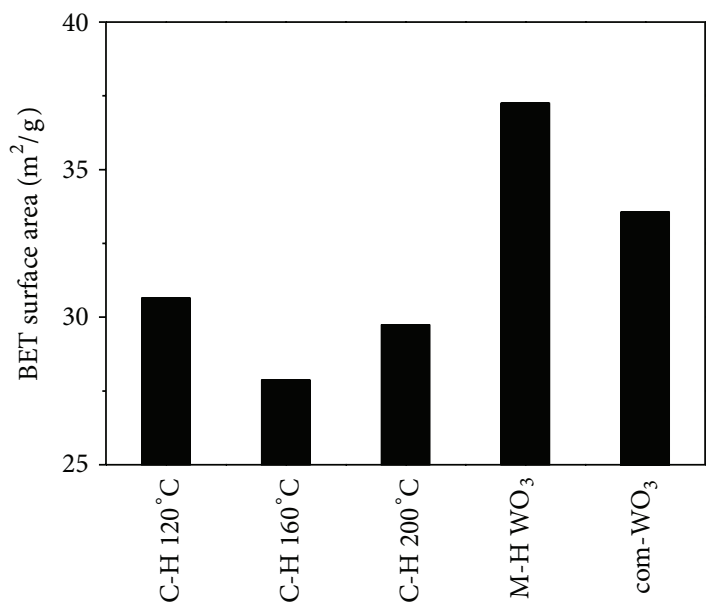

(a)
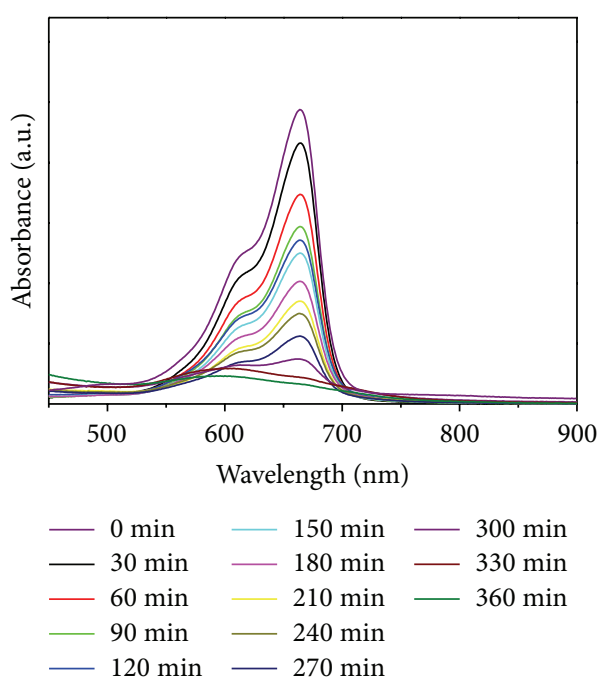

(c)

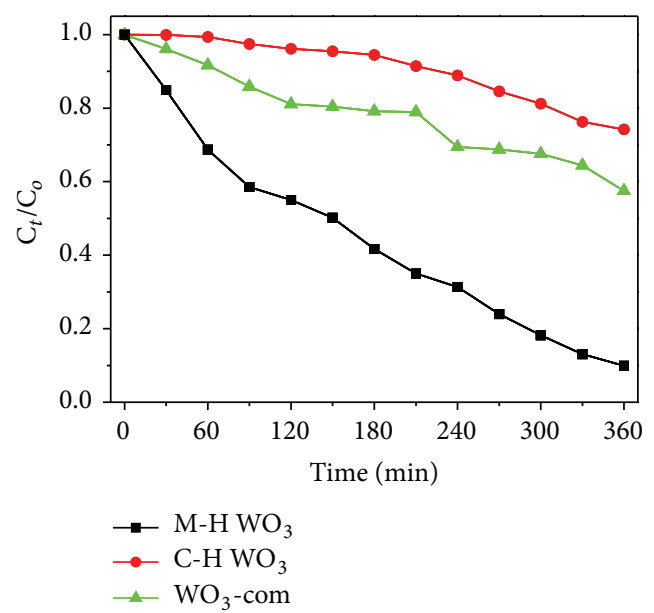

(e)

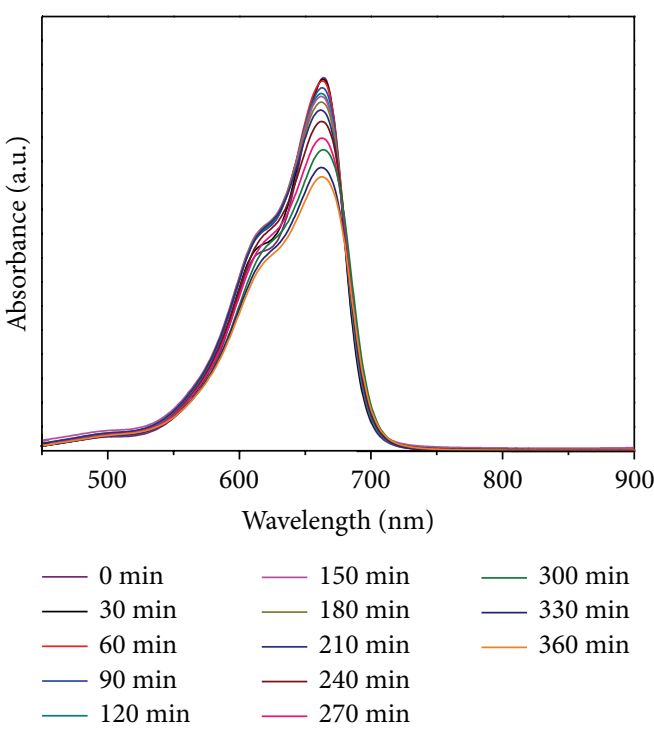

(b)
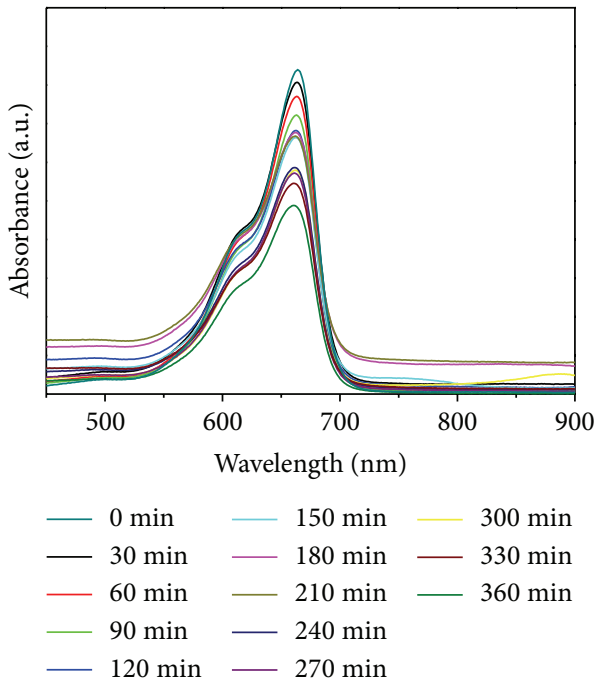

(d)

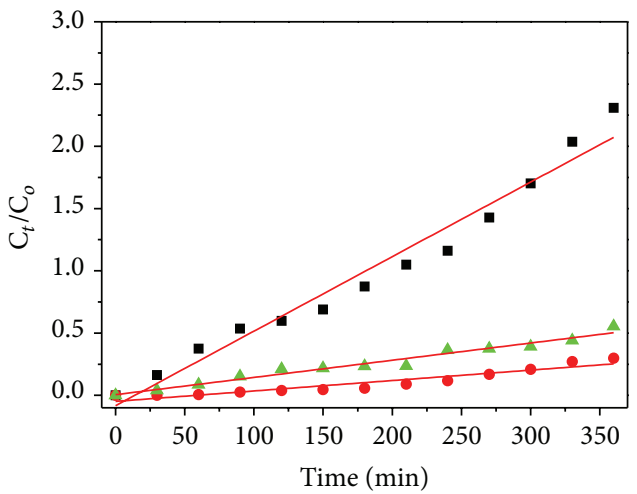

- $\mathrm{M}-\mathrm{H} \mathrm{WO}_{3}$

- $\mathrm{C}-\mathrm{H} \mathrm{WO}_{3}$

- $\mathrm{WO}_{3}$-com

(f)

Figure 6: (a) BET surface areas of the products synthesized by the $\mathrm{C}-\mathrm{H}$ at 120,160 , and $200^{\circ} \mathrm{C}$ for $12 \mathrm{~h}$ and $\mathrm{M}-\mathrm{H}$ at $270 \mathrm{~W}$ for $180 \mathrm{~min}$ and commercial (com) $\mathrm{WO}_{3}$. (b)-(d) UV-visible absorption spectra and (e), (f) photocatalytic degradation kinetics of $\mathrm{MB}$ dye by the $\mathrm{WO}_{3}$ photocatalysts of the $200^{\circ} \mathrm{C} \mathrm{C}-\mathrm{H}$ and $270 \mathrm{~W} \mathrm{M}-\mathrm{H}$ and the commercial $\mathrm{WO}_{3}$ irradiated with UV light for different lengths of time. 
transition. The transitions are directly allowed, indirectly allowed, directly forbidden, and indirectly forbidden for $n$ equals $1 / 2,2,3 / 2$, and 3 , respectively. The absorption was controlled by two photon energy ranges relative to energy gap. For $h v>E_{g}$, absorption is linearly increased with the increasing of photon energy caused by the transition of electrons from the topmost occupied state of valence band to the bottommost unoccupied state of conduction band. For $h v<E_{g}$, the absorption curves are different from linearity, caused by charged transition relating to defects. In the present research, direct energy gaps of the products synthesized by the $\mathrm{C}-\mathrm{H}$ at 120,160 , and $200^{\circ} \mathrm{C}$ for $12 \mathrm{~h}$ were determined to be $2.60,2.96$, and $3.22 \mathrm{eV}$, respectively $[2,29,30]$. In addition, the direct band gap of commercial $\mathrm{WO}_{3}$ was determined to be $2.63 \mathrm{eV}[8]$.

3.7. BET Analysis. The BET analysis was used to determine surface area of the products (Figure 6(a)). It was found that pure $\mathrm{WO}_{3}$ of the $\mathrm{M}-\mathrm{H}\left(37.25 \mathrm{~m}^{2} / \mathrm{g}\right)$ has larger surface area than the product of the $\mathrm{C}-\mathrm{H}$ and commercial $\mathrm{WO}_{3}$ $\left(33.56 \mathrm{~m}^{2} / \mathrm{g}\right)$. Surface area of the product synthesized by the $\mathrm{C}-\mathrm{H}$ at $120^{\circ} \mathrm{C}$ for $12 \mathrm{~h}\left(\mathrm{WO}_{3} \cdot \mathrm{H}_{2} \mathrm{O}\right)$ was determined to be $30.65 \mathrm{~m}^{2} / \mathrm{g}$. Pure $\mathrm{WO}_{3}$ products at 160 and $200^{\circ} \mathrm{C}$ for $12 \mathrm{~h}$ were determined to be 27.87 and $29.74 \mathrm{~m}^{2} / \mathrm{g}$, respectively. The $\mathrm{M}-\mathrm{H}$ processed $\mathrm{WO}_{3}$ nanostructure has different size distributions due to thermal stress during rapid heating, and the $\mathrm{M}-\mathrm{H}$ product is also shown as rough surface. The traces of cracks on the $\mathrm{M}-\mathrm{H}$ nanoplates and small debris separation have the influence to increase surface area.

3.8. Photocatalysis. The photocatalytic activities of $\mathrm{WO}_{3}$ synthesized by the $200^{\circ} \mathrm{C} \mathrm{C}-\mathrm{H}$ and $270 \mathrm{~W} \mathrm{M-H}$ and of the commercial $\mathrm{WO}_{3}$ photocatalyst were evaluated by identifying the degradation of methylene blue $\left(\mathrm{C}_{16} \mathrm{H}_{18} \mathrm{~N}_{3} \mathrm{SCI}, \mathrm{MB}\right)$ under UV radiation. Before UV irradiation, $100 \mathrm{~mL}$ of $1 \times 10^{-5} \mathrm{~mol} / \mathrm{L}$ $\mathrm{MB}$ aqueous solution containing $0.1 \mathrm{~g}$ of photocatalyst was magnetically stirred in the dark for $30 \mathrm{~min}$. For comparison, $\mathrm{WO}_{3}$ synthesized by the $200^{\circ} \mathrm{C}$ of the $\mathrm{C}-\mathrm{H}$ for $12 \mathrm{~h}, \mathrm{WO}_{3}$ of the $270 \mathrm{~W} \mathrm{M}-\mathrm{H}$ for $180 \mathrm{~min}$, and commercial $\mathrm{WO}_{3}$ were used as photocatalytic materials for degrading $\mathrm{MB}$ under UV radiation. Figures 6(b)-6(d) show the UV-visible absorption spectra of $\mathrm{MB}$ in aqueous solution containing $\mathrm{WO}_{3}$ synthesized by the $\mathrm{C}-\mathrm{H}$ and $\mathrm{M}-\mathrm{H}$ methods and commercial $\mathrm{WO}_{3}$ for different lengths of irradiation time. The characteristic absorption peaks of $\mathrm{MB}$ at $664 \mathrm{~nm}$ gradually decrease with the prolonging irradiation time. For $\mathrm{WO}_{3}$ photocatalyst of the $\mathrm{M}-\mathrm{H}$, the characteristic absorption peak decreases almost disappear within $360 \mathrm{~min}$. The MB degradation under a series of the experimental conditions is shown in Figure 6(e), where $C_{o}$ and $C_{t}$ are the initial concentration after the equilibrium absorption and residual concentration of $\mathrm{MB}$ within the length of time $(t)$, respectively. The $\mathrm{MB}$ concentration of $\mathrm{WO}_{3}$ photocatalyst of the $\mathrm{C}-\mathrm{H}$ decreases slower than $\mathrm{WO}_{3}$ of the $\mathrm{M}-\mathrm{H}$ and commercial one under UV radiation. The degradation efficiencies for the $\mathrm{M}-\mathrm{H}$, commercial, and $\mathrm{C}$ $\mathrm{H}$ photocatalysts were $90.07 \%, 42.53 \%$, and $25.80 \%$ within 360 min irradiation, respectively. These results corresponded with the BET analysis. Not only surface area plays the role in the photocatalytic activity but the crystalline composition of the photocatalyst also shows an important effect [31]. The crystalline structure and morphology of the $\mathrm{M}-\mathrm{H}$ and $\mathrm{C}$ $\mathrm{H} \mathrm{WO}_{3}$ (monoclinic, nanoplates) are difference from those of commercial $\mathrm{WO}_{3}$ (orthorhombic, nanorods). They also have the influence to control the photocatalytic rate. The Langmuir-Hinshelwood (L-H) kinetics model was used to investigate the degradation of $\mathrm{MB}$ solution and the pseudofirst-order rate equation was given by [18]

$$
\ln \left(\frac{C_{o}}{C_{t}}\right)=k_{\mathrm{app}} t
$$

where $C_{o}$ is the equilibrium concentration after absorption, $C_{t}$ is the concentration of $\mathrm{MB}$ at time $t$, and $k_{\text {app }}$ represents the apparent pseudo-first-order rate constant of initial degradation. The pseudo-first-order rate constant $\left(k_{\text {app }}\right)$ was calculated from the slope of the $\ln \left(C_{o} / C_{t}\right)$ versus irradiation time $(t)$ shown in Figure $6(\mathrm{f})$. The rate constant of $\mathrm{MB}$ degradation was $0.00599 \mathrm{~min}^{-1}, 8.38072 \times 10^{-4} \mathrm{~min}^{-1}$, and $0.00138 \mathrm{~min}^{-1}$ in the solutions containing the $\mathrm{M}-\mathrm{H} \mathrm{WO}, \mathrm{C}-$ $\mathrm{HWO}_{3}$, and commercial $\mathrm{WO}_{3}$, respectively.

\section{Conclusions}

In summary, $\mathrm{WO}_{3}$ nanoplates were successfully synthesized by the citric acid-assisted conventional hydrothermal reaction at $200^{\circ} \mathrm{C}$ for $12 \mathrm{~h}$. Phase, morphology, and optical properties of the products were investigated. The photocatalytic property of the $\mathrm{C}-\mathrm{H} \mathrm{WO}_{3}$ was evaluated by identifying the degradation of $\mathrm{MB}$ dye under $\mathrm{UV}$ irradiation and compared with the $\mathrm{M}-\mathrm{H} \mathrm{WO}_{3}$ and commercial $\mathrm{WO}_{3}$. The results indicated that the $\mathrm{M}-\mathrm{H} \mathrm{WO}$ nanoplates showed the highest efficiency for the degradation of $\mathrm{MB}$ dye at the rate of $90.07 \%$ under UV illumination within $360 \mathrm{~min}$, corresponding to the BET surface area analysis.

\section{Conflict of Interests}

The authors declare that there is no conflict of interests regarding the publication of this paper.

\section{Acknowledgments}

The authors wish to thank the Thailand Research Fund (TRF) for providing financial support through the Royal Golden Jubilee Ph.D. Program and the TRF Research Grant BRG5380020; the National Nanotechnology Center (NANOTEC), National Science and Technology Development Agency (NSTDA), Thailand, through the project P-10-11345 for Research, Development and Engineering (RD \& E); and the Thailand's Office of the Higher Education Commission through the National Research University (NRU) Project for Chiang Mai University (CMU), including the Graduate School of CMU through a general support. 


\section{References}

[1] L. Li, J. Zhao, Y. Wang et al., "Oxalic acid mediated synthesis of $\mathrm{WO}_{3} \cdot \mathrm{H}_{2} \mathrm{O}$ nanoplates and self-assembled nanoflowers under mild conditions," Journal of Solid State Chemistry, vol. 184, no. 7, pp. 1661-1665, 2011.

[2] V. Hariharan, S. Radhakrishnan, M. Parthibavarman, R. Dhilipkumar, and C. Sekar, "Synthesis of polyethylene glycol (PEG) assisted tungsten oxide $\left(\mathrm{WO}_{3}\right)$ nanoparticles for l-dopa biosensing applications," Talanta, vol. 85, no. 4, pp. 2166-2174, 2011.

[3] J. Polleux, A. Gurlo, N. Barsan, U. Weimar, M. Antonietti, and M. Niederberger, "Template-free synthesis and assembly of single-crystalline tungsten oxide nanowires and their gassensing properties," Angewandte Chemie International Edition, vol. 45, no. 2, pp. 261-265, 2005.

[4] J. Shi, G. Hu, Y. Sun et al., " $\mathrm{WO}_{3}$ nanocrystals: synthesis and application in highly sensitive detection of acetone," Sensors and Actuators B: Chemical, vol. 156, no. 2, pp. 820-824, 2011.

[5] X. Gao, X. Su, C. Yang et al., "Hydrothermal synthesis of $\mathrm{WO}_{3}$ nanoplates as highly sensitive cyclohexene sensor and highefficiency MB photocatalyst," Sensors and Actuators B, vol. 181, pp. 537-543, 2013.

[6] C. Dai, M. Liu, F. Chen, C. Wu, and M. Chang, "A nanowire $\mathrm{WO}_{3}$ humidity sensor integrated with micro-heater and inverting amplifier circuit on chip manufactured using CMOSMEMS technique," Sensors and Actuators, B: Chemical, vol. 123, no. 2, pp. 896-901, 2007.

[7] A. Danine, L. Cojocaru, C. Faure et al., "Room temperature UV treated $\mathrm{WO}_{3}$ thin films for electrochromic devices on paper substrate," Electrochimica Acta, vol. 129, pp. 113-119, 2014.

[8] D. B. Hernandez-Uresti, D. Sánchez-Martínez, A. MartínezdelaCruz, S. Sepúlveda-Guzmán, and L. M. Torres- Martínez, "Characterization and photocatalytic properties of hexagonal and monoclinic $\mathrm{WO}_{3}$ prepared via microwave-assisted hydrothermal synthesis," Ceramics International, vol. 40, no. 3 , pp. 4767-4775, 2014.

[9] S. S. Thind, M. Tian, and A. Chen, "Direct growth and photoelectrochemical study of $\mathrm{WO}_{3}$ nanostructured materials," Electrochemistry Communications, vol. 43, pp. 13-17, 2014.

[10] Z. Gu, T. Zhai, B. Gao et al., "Controllable assembly of $\mathrm{WO}_{3}$ nanorods/nanowires into hierarchical nanostructures," Journal of Physical Chemistry B, vol. 110, no. 47, pp. 23829-23836, 2006.

[11] K. O. Rocha and S. M. Zanetti, "Structural and properties of nanocrystalline $\mathrm{WO}_{3} / \mathrm{TiO}_{2}$-based humidity sensors elements prepared by high energy activation," Sensors and Actuators $B$ : Chemical, vol. 157, no. 2, pp. 654-661, 2011.

[12] K. Murugan, S. B. Chandrasekhar, and J. Joardar, "Nanostructured $\alpha / \beta$-tungsten by reduction of $\mathrm{WO}_{3}$ under microwave plasma," International Journal of Refractory Metals and Hard Materials, vol. 29, no. 1, pp. 128-133, 2011.

[13] J. Sungpanich, T. Thongtem, and S. Thongtem, "Large-scale synthesis of $\mathrm{WO}_{3}$ nanoplates by a microwave-hydrothermal method," Ceramics International, vol. 38, no. 2, pp. 1051-1055, 2012.

[14] S. Komarneni, "Nanophase materials by hydrothermal, microwave-hydrothermal and microwave-solvothermal methods," Current Science, vol. 85, no. 12, pp. 1730-1734, 2003.

[15] L. Sun, X. Zhao, C. Jia et al., "Enhanced visible-light photocatalytic activity of $\mathrm{g}_{-} \mathrm{C}_{3} \mathrm{~N}_{4}$ - $\mathrm{ZnWO} 4$ by fabricating a heterojunction: investigation based on experimental and theoretical studies," Journal of Materials Chemistry, vol. 22, no. 44, pp. 23428-23438, 2012.
[16] S. Nishimoto, T. Mano, Y. Kameshima, and M. Miyake, "Photocatalytic water treatment over $\mathrm{WO}_{3}$ under visible light irradiation combined with ozonation," Chemical Physics Letters, vol. 500, no. 1-3, pp. 86-89, 2010.

[17] W. Chu and Y. F. Rao, "Photocatalytic oxidation of monuron in the suspension of $\mathrm{WO}_{3}$ under the irradiation of UV-visible light," Chemosphere, vol. 86, no. 11, pp. 1079-1086, 2012.

[18] N. A. Ramos-Delgadoa, M. A. Gracia-Pinillab, L. Maya-Treviño, L. Hinojosa-Reyesa, J. L. Guzman-Mara, and A. HernándezRamírez, "Solar photocatalytic activity of $\mathrm{TiO}_{2}$ modified with $\mathrm{WO}_{3}$ on thedegradation of an organophosphorus pesticide," Journal of Hazardous Materials, vol. 263, pp. 36-44, 2013.

[19] "Powder Diffraction File, JCPDS-ICDD," 12 Campus Boulevard, Newtown Square, Pa, USA, 2001.

[20] B. Ingham, S. V. Chong, and J. L. Tallon, "Layered tungsten oxide-based organic-Inorganic hybrid materials: an infrared and raman study," Journal of Physical Chemistry B, vol. 109, no. 11, pp. 4936-4940, 2005.

[21] H. S. Mansur, C. M. Sadahira, A. N. Souza, and A. A. P. Mansur, "FTIR spectroscopy characterization of poly (vinyl alcohol) hydrogel with different hydrolysis degree and chemically crosslinked with glutaraldehyde," Materials Science and Engineering C, vol. 28, no. 4, pp. 539-548, 2008.

[22] H. S. Mansur, R. L. Oréfice, and A. A. P. Mansur, "Characterization of poly(vinyl alcohol)/poly(ethylene glycol) hydrogels and PVA-derived hybrids by small-angle X-ray scattering and FTIR spectroscopy," Polymer, vol. 45, no. 21, pp. 7193-7202, 2004.

[23] S. Salmaoui, F. Sediri, and N. Gharbi, "Characterization of h$\mathrm{WO}_{3}$ nanorods synthesized by hydrothermal process," Polyhedron, vol. 29, no. 7, pp. 1771-1775, 2010.

[24] A. Kuzmin, J. Purans, E. Cazzanelli, C. Vinegoni, and G. Mariotto, "X-ray diffraction, extended $\mathrm{x}$-ray absorption fine structure and Raman spectroscopy studies of $\mathrm{WO}_{3}$ powders and (1-x) $\mathrm{WO}_{3}-\mathrm{y} \cdot \mathrm{xReO}_{2}$ mixtures," Journal of Applied Physics, vol. 84, no. 10, pp. 5515-5524, 1998.

[25] C. S. Rout, M. Hegde, and C. N. R. Rao, " $\mathrm{H}_{2} \mathrm{~S}$ sensors based on tungsten oxide nanostructures," Sensors and Actuators B: Chemical, vol. 128, no. 2, pp. 488-493, 2008.

[26] T. Siciliano, A. Tepore, G. Micocci, A. Serra, D. Manno, and E. Filippo, "WO 3 gas sensors prepared by thermal oxidization of tungsten," Sensors and Actuators, B: Chemical, vol. 133, no. 1, pp. 321-326, 2008.

[27] Y. S. Kim, "Thermal treatment effects on the material and gas-sensing properties of room-temperature tungsten oxide nanorod sensors," Sensors and Actuators B, vol. 137, no. 1, pp. 297-304, 2009.

[28] Y. Keereeta, T. Thongtem, and S. Thongtem, "Fabrication of $\mathrm{ZnWO}_{4}$ nanofibers by a high direct voltage electrospinning process," Journal of Alloys and Compounds, vol. 509, no. 23, pp. 6689-6695, 2011.

[29] Y. Shen, D. Ding, and Y. Deng, "Fabrication and characterization of $\mathrm{WO}_{3}$ flocky microspheres induced by ethanol," Powder Technology, vol. 211, no. 1, pp. 114-119, 2011.

[30] K. Lee, W. S. Seo, and J. T. Park, "Synthesis and optical properties of colloidal tungsten oxide nanorods," Journal of the American Chemical Society, vol. 125, no. 12, pp. 3408-3409, 2003.

[31] M. Lindner, J. Theurich, and D. W. Bahnemann, "Photocatalytic degradation of organic compounds: accelerating the process efficiency," Water Science and Technology, vol. 35, no. 4, pp. 79$86,1997$. 

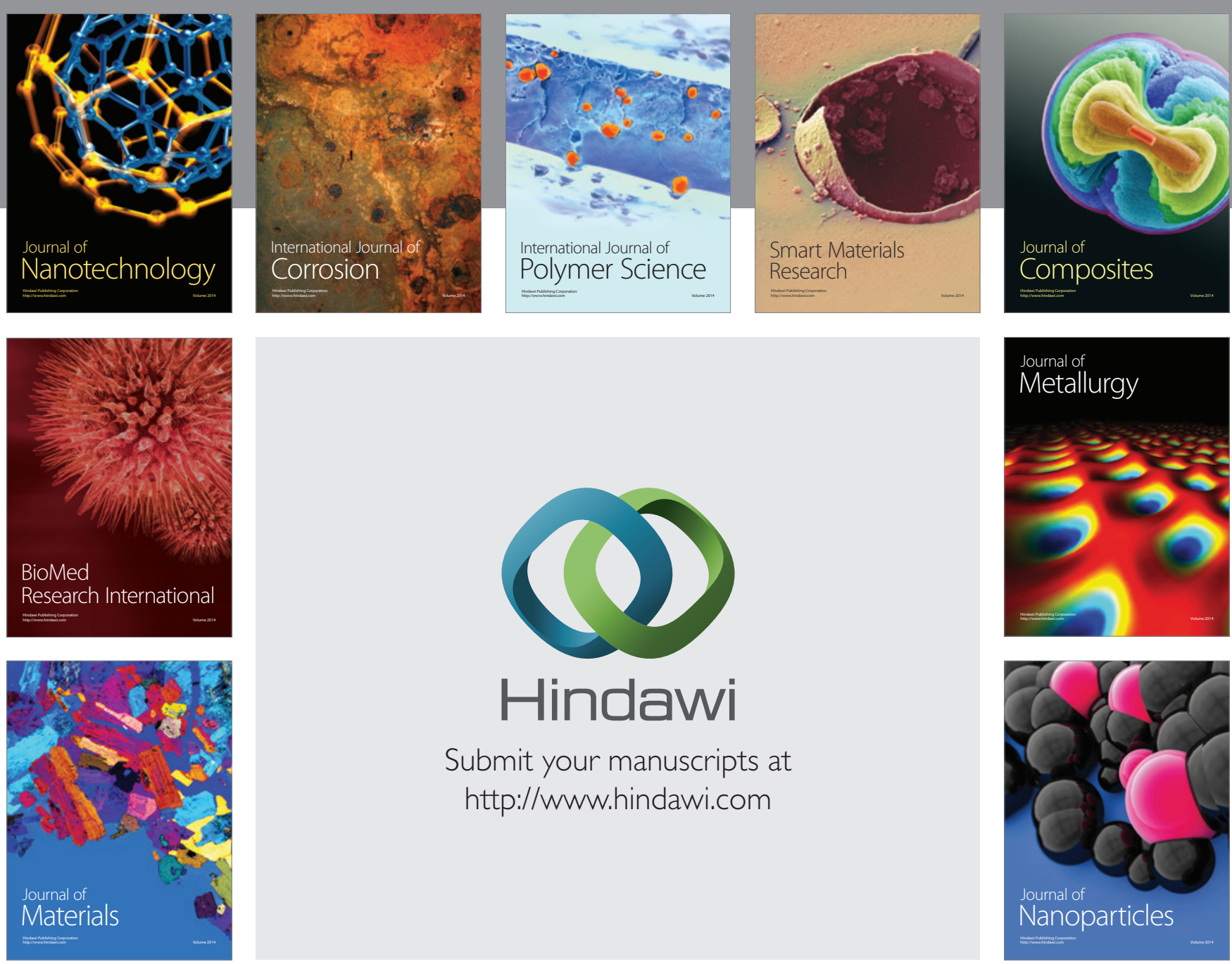

Submit your manuscripts at http://www.hindawi.com
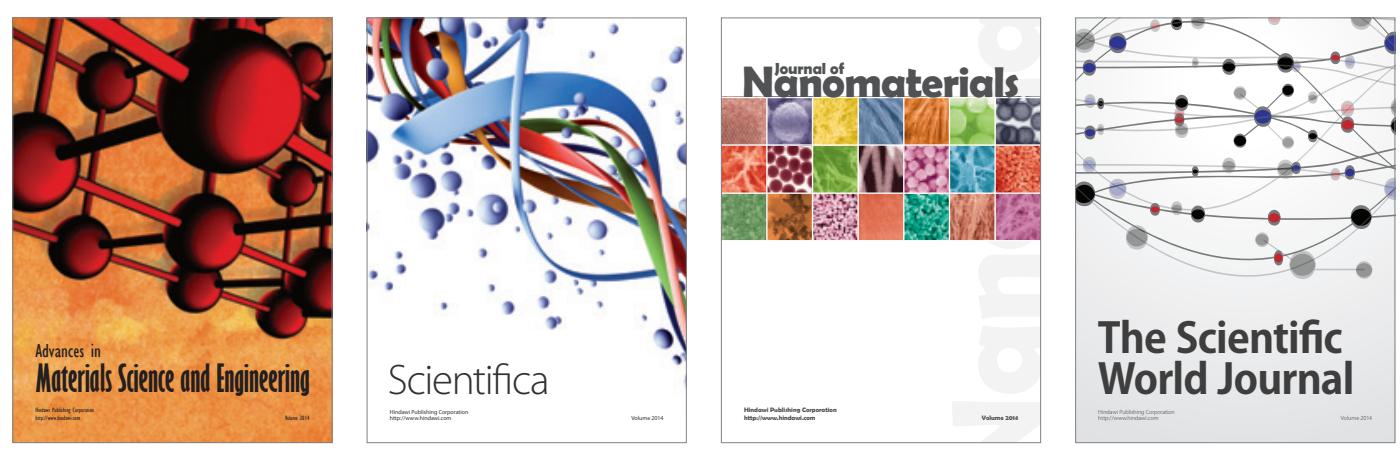

\section{The Scientific World Journal}
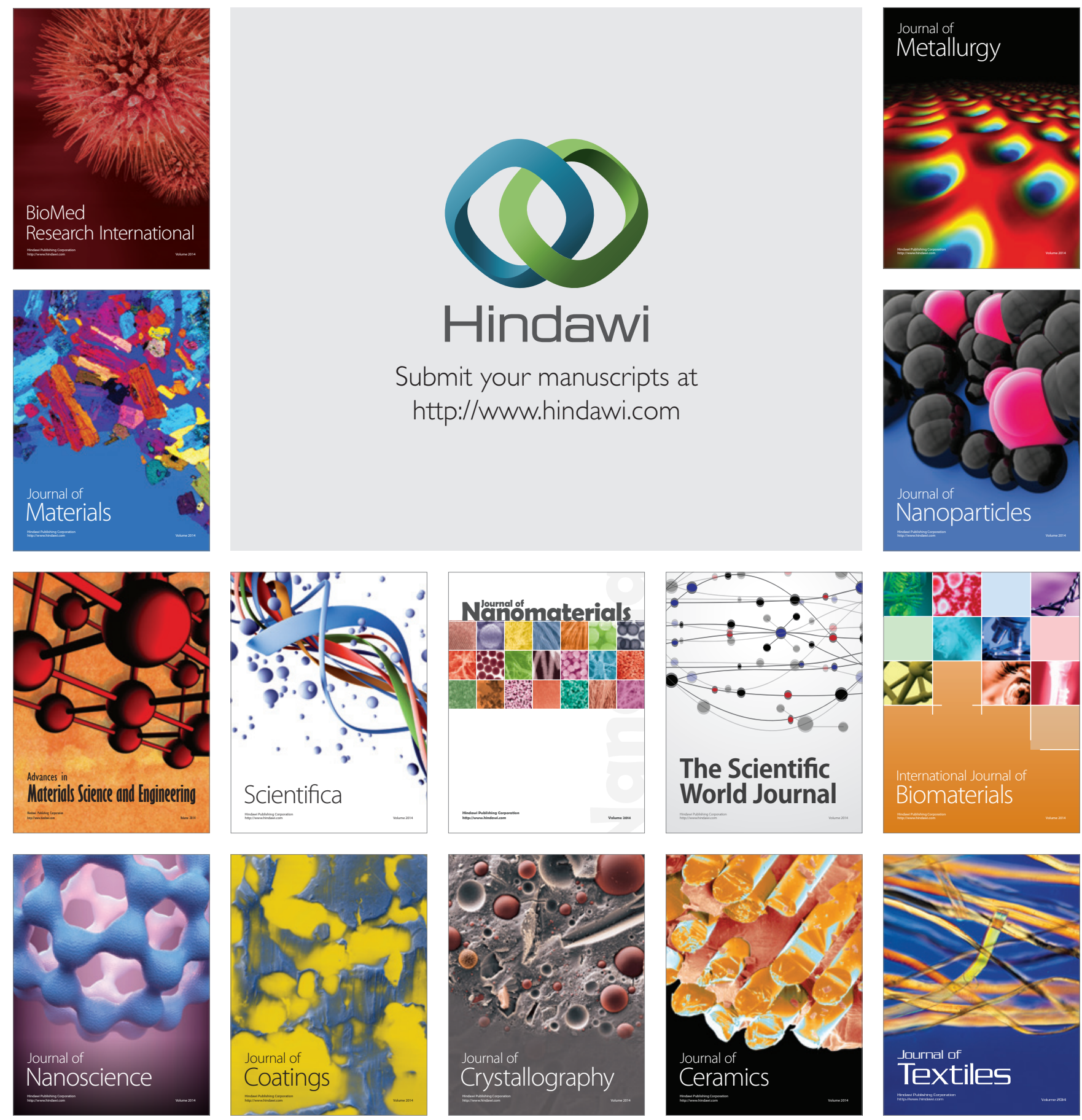